\title{
STRATEGI GURU DALAM PEMBELAJARAN BERHITUNG PEMBAGIAN DI SEKOLAH DASAR
}

\author{
Endang Putri Susanti ${ }^{1}$, Yantoro ${ }^{2}$, Agung Rimba Kurniawan ${ }^{3}$ \\ Program Studi Pendidikan Guru Sekolah Dasar, Fakultas Keguruan dan Ilmu Pendidikan \\ Universitas Jambi \\ Email: endangputri698@gmail.com ${ }^{1}$, yantoro@unja.co.id ${ }^{2}$, agung.rimba@unja.ac.id ${ }^{3}$
}

Website:

https://jurnal.uinantasari.ac.id/index.php/adzka

Received: 10 Juni 2020; Accepted: 29 Juni 2020; Published: 30 Juni 2020

\begin{abstract}
This study aims to describe the teacher's strategy in learning to count division in grade II elementary schools. This research is a qualitative research with case study research type. The subject of the research was the teacher in grade II elementary school. Data collection techniques are carried out through structured interviews and documentation. The data obtained in the form of qualitative data that contains a description of the results of interviews with teachers about the learning strategies of elementary school numeracy division. This research was conducted in class II SD Negeri 155/1 Sungai Buluh. The results showed that the teacher has a learning strategy in learning arithmetic. Based on the division counting indicator, namely the introduction of the concept of dividing, simple division, and teaching the remainder concepts, the teacher applies a learning strategy that can help in the learning process of dividing the division. The learning strategies used by the teacher are direct learning strategies and indirect learning strategies.
\end{abstract}

Keywords: learning strategies; teacher strategies; counting division

\begin{abstract}
ABSTRAK
Penelitian ini bertujuan untuk mendeskripsikan strategi guru dalam pembelajaran berhitung pembagian di kelas II sekolah dasar. Penelitian ini merupakan penelitian kualitatif dengan jenis penelitian studi kasus. Subjek penelitian adalah guru wali kelas II Sekolah Dasar. Teknik pengumpulan data yang dilakukan yaitu melalui wawancara terstruktur dan dokumentasi. Data yang diperoleh berupa data kualitatif yang berisi deskripsi tentang hasil wawancara dengan guru mengenai strategi pembelajaran berhitung pembagian disekolah dasar. Penelitian ini dilakukan di kelas II SD Negeri 155/1 Sungai Buluh. Hasil penelitian menunjukkan bahwa guru memiliki strategi pembelajaran dalam pembelajaran berhitung pembagian. Berdasarkan indikator berhitung pembagian yaitu pengenalan konsep membagi, pembagian sederhana, dan mengajarkan konsep sisa, guru menerapkan strategi pembelajaran yang dapat membantu dalam proses pembelajaran berhitung pembagian tersebut. Adapun strategi pembelajaran yang digunakan guru berupa strategi pembelajaran langsung dan strategi pembelajaran tidak langsung.
\end{abstract}

Kata Kunci : strategi pembelajaran; strategi guru; berhitung pembagian

\section{PEDAHULUAN}

Guru memiliki peranan penting didalam proses pembelajaran. Seorang guru harus memberikan bimbingan belajar bagi peserta didik dalam memahami suatu pembelajaran.Pada kegiatan pembelajaran guru juga harus memahami perkembangan peserta didik serta karakteristiknya. Menurut Piaget yang menyatakan bahwa anak usia berkisar antara 7-11 berada pada tahap operasi konkret (Maulana, 2011:70). Pada tahap operasional konkret, kemampuan peserta didik yaitu berfikir secara logis terhadap suatu objek yang bersifat konkret 
atau nyata dalam kehidupan sehari-hari. Salah satu pembelajaran yang mengaitkan konsep belajar secara abstrak dan bersifat konkret yaitu pembelajaran matematika.

Matematika merupakan pembelajaran yang mempunyai banyak peranan dalam kehidupan sehari-hari, seperti menghitung, mengukur, menimbang dan lain sebagainya. Pada hakikatnya, matematika merupakan ilmu deduktif, terstruktur tentang pola dan hubungan, bahasa simbol, serta sebagai ratu dan pelayanan ilmu (Rusefendi, 2017). Pembelajaran matematika memiliki keteraturan berdasarkan pola yang ditemukan dan menggunakan simbol yang memiliki makna. Menurut undang-undang Nomor 20 Tahun 2003 tentang Sistem Nasional pasal 37 Ayat 1 menyatakan bahwa kurikulum pendidikan dasar sampai menengah wajib memuat: pendidikan kewarganegaraan, agama, matematika, IPA, IPS, seni dan budaya, penjas, keterampilan/kejujuran, serta muatan lokal. Berdasarkan undang-undang tersebut bahwa matematika adalah salah satu mata pelajaran wajib yang harus diajarkan sejak jenjang pendidikan dasar. Matematika sering dianggap rumit bagi peserta didik. Anggapan tersebut membuat peserta didik kurang memahami dan mempelajari matematika lebih dalam. (Miarti dalam Sundayana, 2015:2) menyatakan "meskipun matematika dianggap memiliki tingkat kesulitan yang tinggi, namun setiap orang harus memahaminya karena merupakan sarana untuk menyelasaikan masalah sehari-hari". Oleh sebab itu, perlu mempelajari dan memahami pembelajaran matematika agar dapat mengimplementasikannya didalam kehidupan sehari-hari.

Berhitung pembagian adalah salah satu bentuk operasi hitung didalam pembelajaran matematika. Peran guru dalam pembelajaran berhitung pembagian ssangatlah membantu pada proses pembelajaran selanjutnya. Dalam hal ini guru harus memiliki suatu strategi yang baik untuk menumbuhkan kemampuan peserta didik pada suatu pembelajaran khususnya didalam berhitung pembagian. Secara umun strategi merupakan garis besar yang memiliki tujuan untuk bertindak mencapai suatu tujuan tertentu. Pada proses pembelajaran, strategi diartikan sebagai bentuk umum kegiatan guru dan peserta didik sebagai perwujudan dari tujuan pembelajaran yang telah ditetapkan. Strategi yang dapat dilakukan oleh guru agar peserta didik paham dan tidak merasa bosan dalam suatu pembelajaran, yaitu guru perlu mengiringi sebuah permainan atau dengan menggunakan media pembelajaran yang telah disesuaikan terlebih dahulu dengan materi yang ingin disampaikan. Dengan demikian, peserta didik bisa bermain sambil belajar, tanpa harus merasa takut dan bosan dengan proses pembelajaran, sehingga peserta sedikit demi sedikit dapat memahami suatu konsep dalam pembelajaran tersebut.

Sesuai dengan hasil penelitian terdahulu, menunjukkan bahwa strategi penyampaian pembelajaran matematika yang dibuat oleh guru adalah penyusunan perencanaan penggunaan media pembelajaran berdasarkan tujuan. Strategi penyampaian pembelajaran dapat digunakan dalam upaya meningkatkan prestassi belajar siswa pada pelajaran matematika. Kedua, Hasil penelitian tersebut mengatakan bahwa strategi pembelajaran menjadi faktor utama dalam meningkatkan proses pembelajaran dan keterampilan bahassa. Sehingga dapat meningkatkan mutu kualitas dalam keterampilan berbahssa setiap individu.

Berdasarkan hasil pengamatan yang dilakukan pada hari Selasa tanggal 12 November 2019 di SD Negeri 155/1 Sungai Buluh, peserta didik melakukan operasi hitung dengan baik, mereka saling membantu jika ada teman lainnya sedikit kesulitan dalam mengerjakan operasi hitung pembagian. Peserta didik juga ada yang sudah memahami cara berhitung pembagian. Peneliti juga melakukan wawancara kepada wali kelas mengenai hal tersebut. Guru menyatakan bahwa peserta didik cukup pandai dalam berhitung pada operasi hitung pembagian, peserta didik juga lebih termotivasi dalam proses pembelajaran saat guru mengajarkan matematika diiringi dengan bermain sambil belajar, sehingga peserta didik akan lebih mudah memahami dalam berhitung pembagian. Guru menggunakan bermacam media pembelajaran yang dapat membantu jalannya proses pembelajaran berhitung pembagian guna memperdalam bagaimana 
strategi yang digunakan guru, maka perlu dilakukan kajian yang mendalam. Dengan demikian, perlu dikaji lebih dalam tentang strategi-strategi pembelajaran yang digunakan oleh guru untuk

\section{METODE PENELITIAN}

Penelitian ini merupakan penelitian kualitatif dengan jenis penelitian Studi Kasus. Studi kasus merupakan metode penelitian dalam ilmu sosial, dan dengan melakukan riset atau pemeriksaan mendalam mengenai suatu kejadian. Studi kasus juga dapat digunakan untuk menyelidiki suatu peristiwa, situasi, atau suatu kondisi sosial tertentu dan dapat memberikan wawasan dalam proses yang menjelaskan bagaimana peristiwa situasi tertentu terjadi (Hodgetts dalam Unika, 2018:126). Selain itu dalam proses penelitian ini yaitu memperoleh data deskriptif beberntuk tulisan-tulisan yang berasal dari informan.

Subjek penelitian adalah guru wali kelas II Sekolah Dasar. Teknik pengumpulan data yang dilakukan yaitu melalui wawancara terstruktur dan dokumentasi. Data yang diperoleh berupa data kualitatif yang berisi deskripsi tentang hasil wawancara dengan guru mengenai strategi pembelajaran berhitung pembagian disekolah dasar. Penelitian ini dilakukan di kelas II SD Negeri 155/1 Sungai Buluh. Uji validitas dalam penelitian ini menggunakan teknik validitas triangulasi teknik untuk menguji kredibelitas data dengan cara mengecek data kepada sumber yang sama dengan teknik yang berbeda. Teknik analisis data dengan menggunakan pendapat menurut Stake (dalam Sri Wahyuni 2013:6) bahwa terdiri dari empat tahapan yang dapat digunakan untuk menganalisis data pada penelitian study kasus ini yaitu: (1) pengumpulan kategori, (2) interpretasi langsung, (3) Peneliti membentuk pola dan mencari kesepadanan antara dua atau lebih kategori, (4) mengembangkan generalisasi naturalistik.

\section{HASIL DAN PEMBAHASAN}

Sebagai seorang guru, tentu harus mempunyai cara sendiri dalam menentukan susunan kegiatan pembelajaran dan juga selalu mencari cara maupun solusi untuk melaksanakan kegiatan pembelajaran tersebut. Dalam cara atau susunan yang dipilih untuk menentukan urutan kegaiatan pembelajaran tersebut, tentunya dengan keyakinan akan keberhasilan dalam proses pembelajaran. Strategi merupakan rencana atau prosesdur yang terdapat langkah-langkah untuk mencapai sebuah tujuan, maka didalam pembelajaran guru perlu membuat rancangan terlebih dahulu dan langkah-langkah agar tercapainya suatu rangkaian yang telah dibuat. Untuk membuat suatu strategi, guru perlu memperhatikan atau mengenali karakteristik peserta didik terlebih dahulu dan mampu menempatkan suatu model, media dan strategi dengan baik serta keadaan didalam suatu pembelajaran. Peneliti juga mendapatkan beberapa temuan yang dapat menggambarkan berhitung pembagian yang terdapat pada indikator berhitung pembagian dari Nanang Priatna (2018) yaitu, mengenalkan konsep membagi, pembagian sederhana, dan mengajarkan konsep sisa.

\section{Pengumpulan Kategori}

Pada tahap pengumpulan kategori ini yang terkumpul dari wawancara dengan wali kelas dirangkum, diseleski dan juga difokuskan pada hal-hal yang penting. Adapun pengumpulan kategori yang dilakukan dengan memilih dan menyisihkan data yang kurang bermakna agar apat memberikan gambaran yang jelas serta mempermudahkan bagi sipeneliti untuk melakukan pengumpulan data selanjutnya.

\section{Pengumpulan Kategori Data Wawancara Guru}

Wawancara dilakukan pada hari Selasa 4 Mei 2020 dan 8 Mei 2020 dengan menggunakan teknik wawancara terstrktur, yang berkaitan dengan pembelajaran berhitung pembagian. Hasil wawancara seebagai berikut 


\section{a. Deskripsi Hasil Penelitian}

Berdasarkan hasil wawancara yang dilakukan peneliti dengan guru wali kelas 2 yang berinisial "M" pada hari Selasa 4 Mei 2020, guru mengatakan bahwa kondisi yang dialami peserta didik mengenai pembelajaran berhitung pembagian yaitu peserta didik sudah terbiasa berhitung dengan cara menghafal dan terbiasa berhitung secara manual seperti menggunakan alat bantu tangan dan juga menulis. Hal tersebut terlihat pada saat setiap proses pembelajaran.

Permasalahan yang terdapat pada peserta didik mengenai pembelajaran berhitung pembagian pada pengenalan konsep membagi, guru mengatakan bahwa permalasalahan tersebut karena peserta didik yang hanya terbiasa dalam menghafal perkalian. Apabila peserta didik hanya menghafal perkalian, dan tidak menerapkan cara didalam proses perkalian tersebut maka peserta didik akan terhambat dalam melakukan operasi hitung pembagian. Hal ini sesuai dengan hasil wawancara dengan guru wali kelas 2 yang berinisial " $M$ " yang mengatakan bahwa peserta didik hanya menghafal saja (Wawancara hari Selasa 4 Mei 2020).

Guru melakukan tindakan untuk membantu kesulitan peserta didik dalam pengenalan konsep membagi. Adapun yang guru lakukan untuk membantu kesulitan peserta didik dalam pengenalan konsep membagi yaitu bisa menggunakan alat peraga atau media pembelajaran, misalnya dengan buah-buahan atau yang ada disekitar peserta didik. Hal ini sesusai dengan wawancara dengan guru wali kelas 2 yang berinisial "M" yang mengatakan juga bahwa dalam menyampaikan konsep pada materi berhitung yaitu dengan diterangkan secara berulang-ulang dengan memberi rumusan, bahwa pembelajaran pembagian itu harus dibantu dengan mengenal rumusan bagi kali kurang.

Faktor yang menyebabkan kesulitan peserta didik dalam berhitung pembagian yaitu peserta ragu dalam mengerjakan soal dan juga masih terlalu terfokus pada hafalan saja. Dalam artian peserta didik tersebut ada yang hafal perkalian ada yang tidak dan juga peserta didik masih terfokus pada satu objek saja seperti menghafal perkalian dengan bantuan tangan, karena jika peserta didik sudah hafal perkalian, maka akan membantu pada proses berhitung pembagian. Pernyataan tersebut sesuai dengan hasil wawancara peniliti dengan guru wali kelas 2 yang berinisial "M" yang mengatakan peserta didik pandai dalam berhitung hanya saja masih ragu dalam mengerjakan soal pembagian.

Pada pengenalan konsep membagi, guru mempunyai strategi pembelajaran untuk membantu peserta didik dalam pengenalan konsep membagi yaitu strategi pembelajaran langsung, yaitu yang peserta didik lebih berpusat pada guru dan terkadang juga mengunakan strategi pembelajaran tidak langsung, yaitu adanya interaksi antara peserta didik dengan guru itu sendiri. hal ini sesuai dengan hasil wawancara dengan guru wali kelas 2 yang berinisial "M" yang mengatakan bahwa dengan menggunakan strategi tersebut, peserta didik bisa lebih mudah memahami pada proses pembelajaran.

Guru menggunakan media pembelajaran untuk membantu kesulitan yang dialami peserta didik saat operasi hitung pembagian sederhana. Media sederhana yang guru gunakan terdapat disekitar lingkungan peserta didik. Media konkret yang guru gunakan berupa media yang dapat langsung peserta didik gunakan dalam operasi hitung pembagian sederhana. Hal ini sesuai dengan hasil wawancara dengan guru wali kelas 2 yang berinisial " $M$ " yang mengatakan bahwa media pembelajaran dapat membantu peserta didik pada operasi hitung pembagian sederhana (Wawancara hari Selasa 6 Mei 2020). Pada pengajaran pembagian sederhana kepada peserta didik, guru memiliki solusi yang diterapkan berupa dari pembagian tersebut diajarkan dengan angka yang terkecil terlebih dahulu, contohnya seperti pembagian dua angka dengan dua angka, dan yang tiga angka dengan tiga angka. Hal ini sesuai dengan hasil wawancara dengan guru wali kelas 2 yang berinisial " $M$ " yang mengatakan pengajaran pembagian sederhana tersebut dikenalkan dengan menggunakan angka terkecil terlbih dahulu sebagi pembagi. 
Adapun faktor yang menyebabkan peserta didik mengalami kesulitan dalam pembagian sederhana adalah peserta didik sedikit ragu dalam mengerjakan soal berhitung pembagian. Hal tersebut sesuai dari hasil wawancara dengan guru wali kelas 2 yang berinisial "M" yang mengatakan peserta didik yang ragu dalam mengerjakan soal pembagian sederhana tersebut menjadi hambatan peserta didik ketika melanjutkan dalam mengerjakan soal, tetapi peserta didik ada usaha dengan berani bertanya kepada guru ketika bingung dalam mengerjakannya. Guru menggunakan metode pembelajaran yang digunakan ketika pembelajaran berhitung pembagian. Hal tersebut sesuai dengan hasil wawancara dengan guru wali kelas 2 yang berinisial " $\mathrm{M}$ " yang mengatakan bahwa guru menggunakan metode yang digunakan yaitu metode ceramah, metode diskusi, dan metode demonstrasi sesuai dengan kondisi pembelajaran.

Pada saat pembelajaran berlangsung, guru juga menggunakan strategi pembelajaran yang digunakan untuk membantu berhitung pembagian sederhana peserta didik. Hal ini sesuai dengan hasil wawancara dengan guru wali kelas 2 yang berinisial " $M$ " yang mengatakan bahwa strategi yang digunakan yaitu strategi pembelajaran langsug, yaitu yang peserta didik lebih berpusat pada guru dan terkadang juga mengunakan strategi pembelajaran tidak langsung, yaitu adanya interaksi antara peserta didik dengan guru itu sendiri. Pembelajaran matematika yang guru gunakan sudah dapat membantu peserta didik dalam memahami materi konsep sisa pada pembelajaran berhitung pembagian. Hal ini sesuai dengan hasil wawancara dengan guru wali kelas 2 yang berinisial "M" yang mengatakan bahwa alhamdulilah peserta didik sedikit sudah memahami materi konsep sisa pada pembelajaran berhitung pembagian (Wawancara hari Jum'at 8 Mei 2020).

Guru memiliki kendala dalam mengajarakan pembelajaran berhitung pembagian tentang konsep sisa. Hal ini sesuai dengan hasil wawancara guru wali kelas 2 yang berinisial " $M$ " yang mengatakan bahwa kendala yang guru dapatkan ketika peserta didik masih ada yang belum hafal perkalian dan juga peserta didik yang hanya terfokus pada mengahafal saja tanpa memahami proses operasi hitungnya. Untuk menarik perhatian peserta didik agar mereka lebih optimal dalam memahami materi pada pembelajaran matematika tentang konsep sisa, guru memiliki cara yang dapat diterapkan untuk menarik perhatian peserta didik dalam pembelajaran. Hal ini sesuai dengan hasil wawancara dengan guru wali kelas 2 yang berinisial "M" yang mengatakan untuk menarik perhatian peserta didik agar lebih optimal dalam memahami materi pada pembelajaran matematika tentang konsep sisa tersebut yaitu dengan menggunakan alat peraga atau media pembelajaran dan model pembelajaran yang menarik supaya peserta didik tetap semangat dalam belajar, maka sebelum belajara melakukan peregangan atau belajar sambil bermain.

Upaya yang guru lakukan untuk membantu peserta didik yang belum bisa memahami konsep sisa tersebut adalah dengan melakukan pendeketan khusus pada peserta didik. Hal ini sesuai dengan hasil wawancara dengan guru wali kelas 2 yang berinisial "M" yang mengatakan bahwa dengan upaya yang dilakukan yaitu dengan melakukan pendekatan khusus pada anak yang masih bermasalah dalam berhitung pembagian, sehingga anak akan berani dalam menyampaikan yang belum diketahuinnya. Untuk mengatasi hal tersebut, guru menggunakan strategi pembelajaran sehingga dapat membantu peserta didik dalam memahami konsep sisa. Hal ini sesuai dengan hasil wawancara dengan guru wali kelas 2 yang berinisial " $M$ " yang mengatakan strateginya yaitu dengan menggunakan strategi pembelajaran langsung, dimana disini guru menjelaskan terlebih dahulu dengan menggunakan metode ceramah, kemudian baru diterapkan pada peserta didiknya sehingga ada interaksi antara peserta didik dan guru (Wawancara hari Jum'at 8 Mei 2020). 


\section{Interprestasi Langsung}

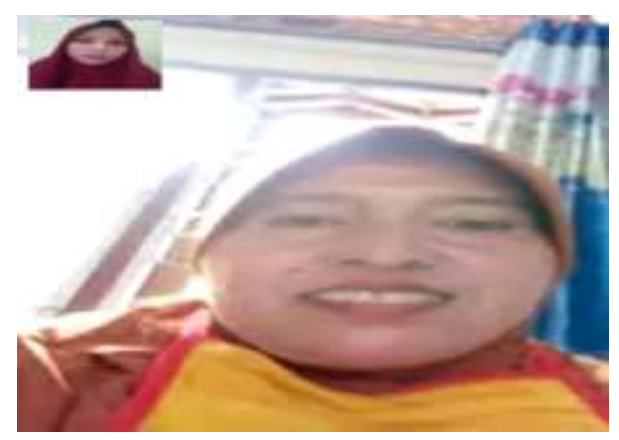

Gambar 1. Wawancara dengan Guru

Interprestasi adalah suatu proses untuk menyusun serta mengorganisasikan data agar lebih mudah dipahami. Interprestasikan langsung data ini yaitu dilakukan dengan cara uraian singkat tentang data yang diperoleh. Data yang diperoleh yaitu data dari wawancara dengan guru wali kelas II, berkaitan dengan pembelajaran berhitung pembagian yang merujuk pada tiga indikator menurut Nanang Priatna (2018), sebagai berikut:

\section{a. Mengenalkan Konsep Membagi}

Pada operasi hitung pembagian terlebih dahulu mengenalkan konsep membagi itu sendiri. Apabila peserta didik memahami konsep membagi itu sendiri, maka akan membantu peserta didik saat melakukan operasi hitung tersebut. Berdasarkan hasil wawancara Senin (4 Mei 2020) dengan guru wali kelas berinisial M didapati bahwa kesulitan yang dialami peserta didik pada pembelajaran berhitung pembagian ini jika peserta didik ragu dalam pembagian berhitung itu sendiri. peserta didik sudah bisa dalam berhitung pembagian hanya saja masih ada yang ragu dalam berhitung pembagian, sehingga peserta didik harus lebih mengenal konsep membagi itu sendiri. Adapun solusi yang guru berikan untuk menyampaikan konsep pada materi hitung itu sendiri dengan diterangkan atau dijelaskan secara berulang - ulang dengan memberi suatu rumusan bahwa pembelajaran pembagian tersebut harus dengan mengenal rumusan bagi kali kurang, karena pembagian itu sendiri merupakan suatu proses yang dilakukan dengan pengurangan secara berulang-ulang. Hal yang guru lakukan untuk membantu kesulitan yang dialami peserta didik dalam pengenalan konsep membagi adalah dengan menggunakan alat peraga atau menggunakan media pembelajaran yang ada disekitar peserat didik. Adapun media yang dapat membantu peserta didik dalam pengenalan konsep membagi seperti menggunakan buah-buahan untuk membantu menggitung atau operasi hitung pembagian itu sendiri, lidi dan media lainnya yang ada disekitar peseta didik.

Faktor yang menyebabkan kesulitan peserta didik dalam berhitung pembagian adalah terdapat peserta didik ragu dalam mengerjakan soal. Dalam artian peserta didik tersebut ada yang hafal perkalian ada yang tidak, karena jika peserta didik sudah hafal perkalian, maka akan membantu pada proses berhitung pembagian. kurang memahami soal yang diberikan oleh guru. Pada proses pembelajaran, peserta didik juga sudah menghafal perkalian, maka akan membantu sekali pada operasi hitung pembagian itu sendiri. Saat proses pembelajaran, guru menggunakan strategi pembelajaran yang dapat membantu pada pengenalan konsep membagi. Strategi pembelajaran yang guru gunakan yaitu dengan mengaitkan konsep pembelajaran baru dengan pembelajaran yang sudah dikenal peserta didik sebelumnya. Guru juga menggunakan strategi pembelajaran kerja sama atau kerja berkelompok, karena dengan kerja berkelompoklah peserta didik bisa saling membantu dalam mengatasi masalah.

Dari pernyataan diatas maka dapat disimpulkan bahwa peserta didik sudah bisa dalam berhitung pembagian, hanya saja sedikit ragu saat mengerjakannya. Guru juga menggunakan 
media pembeljaran sederhana dalam proses pembelajaran serta menggunakan strategi pembelajaran yang dapat diterapkan dalam proses operasi hitung pembagian.

\section{b. Pembagian Sederhana}

Pembagian sederhana dapat dilakukan dengan pengurangan secara berulang hingga hasilnya 0 (nol). Peserta didik perlu memahami juga pembagian paling dasar terlebih dahulu dan menggunakan angka yang kecil sebagai pembagi, sehingga peserta didik dapat melakukan operasi hitung dengan melakukan pengurangan secara berulang. Dari hasil wawancara pada Rabu (8 Mei 2020) dengan guru wali kelas dengan inisial M mengatakan bahwa dalam proses pembelajaran berhitung pembagian sederhana, guru menggunakan media sebagai alat peraga yang membantu jalannya proses pembelajaran peserta didik. Solusi guru saat mengajarkan pembagian sederhana itu sendiri yaitu menggunakan angka yang terkecil terlebih dahulu, contohnya seperti pada pembagian dua angka dengan dua angka, dan tiga angka dengan tiga angka, karena untuk membantu proses peserta didik melakukan operasi hitung dengan menggunakan angka terbesar.

Pada pembelajaran pembagian sederhana terdapat faktor yang menyebabkan peserta didik masih kesulitan dalam pembagian sederhana itu sendiri. Faktor yang dialami peserta didik salah satunya yaitu masih ragu mengerjakan soal berhitung pembagian. Guru juga menggunakan metode pembelajaran yang sangat membantu peserta didik dalam proses berhitung pembagian. Adapun metode yang digunakan oleh guru adalah dengan menggunakan metode ceramah, metode diskusi, dan metode demonstrasi sesuai dengan kondisi pembelajaran. Guru juga menggunakan strategi yang diterapkan didalm proses pembelajaran berhitung pembagian itu sendiri. Strategi pembelajaran yang digunakan yaitu strategi pembelajaran langsung, dimana peserta didik lebih berpusat pada guru dan terkadang juga menggunakan strategi pembelajaran tidak langsung yaitu adanya interaksi antara peserta didik dengan guru saat proses pembelajaran.

Berdasarkan pernyataan diatas, maka dapat disimpulkan bahwa dalam pembagian sederhana perlu dipahami hal dasar yang dilakukan sebelum melakukan pembagian sederhana. Berhitung pembagian adalah proses pengurangan yang dilakukan secara berulang-ulang. Dalam pembelajaran matematika berhitung pembagian ini, guru juga menggunakan metode ceramah, metode diskusi, serta metode demonstrasi dalam penerapannya. Guru juga menerapkan strategi pembelajaran didalm proses pembelajaran berhitung pembagian tersebut.

\section{c. Mengajarkan Konsep Sisa}

Mengajarkan konsep sisa pada pembagian yaitu mengenalkan susunan pada pembagian itu sendiri yaitu tidak semua bilangan dapat habis dibagi. Untuk dapat mengenalkan konsep sisa pada peserta didik yaitu dapat dicontoh kan dengan bilangan yang kecil terlebih dahulu, misalnya $10: 3$ maka akan terdapat sisa yang tidak habis dibagi. Berdasarkan hasil wawancara guru Kamis ( 9 Mei 2020) bahwa pembelajaran matematika yang guru gunakan dapat membantu peserta didik dalam memahami konsep sisa pada berhitung pembagian, seperti guru menggunakan media sederhana yang ada disekitar peserta didik dalam proses operasi hitung pembagian. Guru juga memiliki kendala dalam mengajarkan pembelajaran berhitung pembagian tentang konsep sisa itu sendiri. Adapun kendala yang dialami guru adalah ketika peserta didik masih kurang dalam perkalian itu sendiri, jika peserta didik hafal perkalian, maka akan membantu peserta didik pada penyelesaian operasi hitung pembagian tersebut. Tetapi guru memiliki cara yang dapat menarik perhatian peserta didik agar mereka lebih optimal dalam memahami konsep sisa pada pembagian. Guru menggunakan alat peraga yang sederhana, tetapi dapat menarik peserta didik untuk mengikuti proses pembelajaran berhitung. Sebelum melakukan operasi hitung pembagian, guru biasanya melakukan permainan sederhana yang 
berkaitan dengan pembelajaran berhitung, ataupun bisa dikatakan belajar sambil bermain dan menggunakan model pembelajaran yang menarik.

Upaya yang guru lakukan untuk membantu peserta didik yang belum memahami konsep sisa adalah dengan melakukan pendekatan khusus pada peserta didik yang masih bermasalah dalam berhitung pembagian. Adapun strategi pembelajaran guru untuk mengatasi hal tersebut yang dapat membantu peserta didik dalam memahami konsep sisa yaitu guru menggunakan strategi pembelajaran langsung, dimana guru menjelaskan terlebih dahulu dengan menggunakan metode ceramah, kemudian baru diterapkan pada peserta didiknya sehingga terdapat interaksi antara peserta didik dengan guru. Dari hasil pernyataan diatas, dapat disimpulkan bahwa dalam mengajarkan konsep sisa pada pembagian ini dapat dicontohkan dengan menggunakan angka kecil terlebih dahulu pada peserta didik. Guru juga menggunakan media pembelajaran sederhana untk membantu proses operasi hitung pembagian.

\section{Peneliti Membentuk Pola dan Mencari Kesepadanan Antara Dua atau Lebih Kategori}

Berdasarkan hasil wawancara dengan guru wali kelas peneliti mendapati temuan bahwa dalam berhitung pembagian, peserta didik perlu diperkenalkan terlebih dahulu mengenai konsep pembagian itu sendiri. Pada pembelajaran berhitung pembagian terdapat keterhubungan dengan konsep pengurangan, yaitu dapat diartikan bahwa pembagian tersebut sebagai pengurangan yang dilakukan secara berulang-ulang. Pembagian sederhana yang dapat dilakukan peserta didik dapat dibantu dengan adanya media pembelajaran yang ada disekitar peserta didik itu sendiri, sehingga peserta didik dapat memahami langsung operasi hitung pembagian sederhana itu sendiri. Peserta didik yang masih belum bisa memahami operasi hitung pembagian, guru melakukan pendekatan khusus pada peserta didik tersebut, dan menerapkan berbagai strategi pembelajaran yang dapat membantu peserta didik seperti strategi pembelajaran langsung dan strategi pembelajaran tak langsung.

\section{Mengembangkan Generalisasi Naturalistik}

Berhitung pembagian adalah hal dasar yang terdapat didalam suatu operasi hitung matematika, sebagaimana pada operasi hitung pembagian yang dilakukan dengan proses pengurangan secara berulang-berulang. Operasi hitung pembagian pada siswa sekolah dasar dibantu dengan menggunakan berbagai media pembelajara sederhana yang terdapat di lingkungan sekitar peserta didik. Media pembelajaran sederhana yang digunakan guru dalam proses berhitung pembagian dapat berupa lidi yang dipotong kecil-kecil serta media sederhana lainnya. Adapun tujuan guru menggunakan media pembelajaran ini untuk mempermudah peserta didik mempelajari konsep dasar, melakukan pembagian sederhana, serta mengajarkan konsep sisa pada pembagian itu sendiri serta proses operasi hitung pada pembagian, karena peserta didik kelas rendah lebih mudah mengingat jika dibantu dengan benda konkret atau secara langsung.

Berdasarkan hasil wawancara yang dilakukan, guru mengatakan bahwa peserta didik juga mempelajari konsep pembagian yang dasarnya berkaitan dengan pengurangan. Apabila peserta didik memahami pengurangan, maka mempermudah peserta didik pada proses operasi hitung pembagian. Pembagian adalah pengurangan yang dilakukan secara berulang-ulang.

\section{Uji Keabsahan Data}

Untuk menetapkan keabsahan data pada penelitian ini maka dilakukan pengujian. Pengujian tersebut dilakukan dengan menggunakan trianglusasi teknik, yang dilakukan dengan mengecek data dengan sumber yang sama dengan teknik yang berbeda. Hasil wawancara 
bersama dengan wali kelas mengenai berhitung pembagian dalam proses pembelajaran didukung dengan bukti nyata yang didapatkan peneliti melalui dokumentasi. Pada hasil dokumentasi juga terdapat peserta didik bekerja sama dalam melakukan operasi hitung pembagian. Dari hasil data tersebut didapati hasil yang sama dan diperkuat dengan dokumentasi berupa foto serta rekaman.

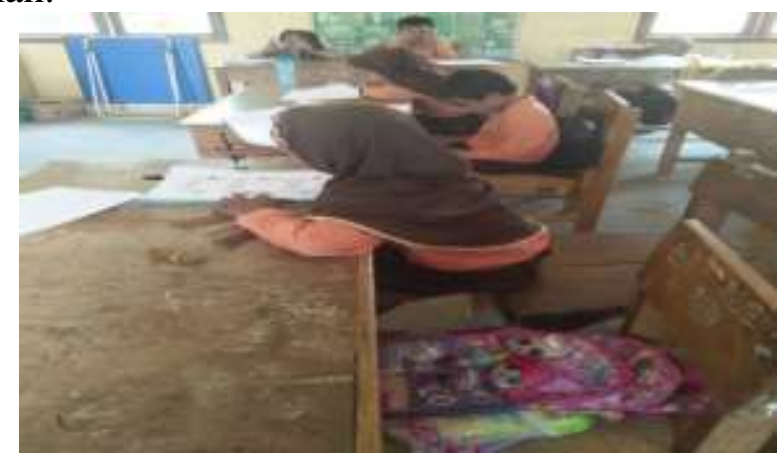

Gambar 2. Peserta Didik Melakukan Operasi Hitung Pembagian

Proses pembelajaran terdapat suatu strategi yang membantu jalannya suatu proses pembelajaran. Perlu adanya motivasi guru untuk membantu peserta didik lebih semangat dalam mengikuti pembelajarannya. Majid (2013:10) mengatakan jenis-jenis startegi pembelajaran dibedakan menjadi dua yaitu strategi pembelajaran dedukif yang merupakan bahan pelajaran yang diolah dari umum atau rumusan yang bersifat khusus, dan sedangkan strategi pembelajaran induktif yang merupakan bahan ajarannya diolah mulai dari yang khusus ke yang sifat umum. Terlihat di SD Negerei 155/I Sungai Buluh, guru menggunakan strategi pembelajaran pada berhitung pembagian. Tujuan dari strategi pembelajaran tersebut diharapkan dapat membantu dalam berhitung pembagian pada peserta didik. Adapun yang terdapat didalam strategi pembalajaran juga terdapat metode pembelajaran yang digunakan oleh guru seperti menggunakan metode ceramah, metode diskusi, serta metode demonstrasi.

Berdasarkan hasil temuan peneliti yang dikuatkan dengan wawancara dan dokumentasi yang telah dilakukan, berhitung pembagian di kelas II SD Negeri 155/1 Sungai Buluh sudah terlihat dalam proses pembelajaran berhitung pembagian. Secara umum peserta didik pandai dalam berhitung, hanya saja sedikit ragu ketika mengerjakan soal pada pembelajaran berhitung pembagian. Kondisi pembelajaran yang dialami peserta didik mengenai pembelajaran berhitung pembagaian yaitu peserta didik sudah terbiasa dengan cara menghafal dan menggunakan alat bantu tangan dalam operasi hitung. Apabila peserta didik hanya menghafal perkalian, dan tidak menerapkan cara didalam proses perkalian tersebut maka akan terhambat dalam melakukan operasi pembagian, tetapi peserta didik ada usaha dengan berani bertanya kepada guru ketika bingung dalam mengerjakannya.

Dalam berhitung pembagian, peserta didik perlu memahami konsep membagi itu sendiri. Guru mengenalkan konsep membagi pada peserta didik dengan melakukan penjelasan secara berulang-ulang bahwa pembagian tersebut harus dengan mengenal rumusan bagi kali kurang, karena pembagian adalah proses pengurangn secara berulang-ulang dan didalam pembagian juga berkaitan dengan operasi perkalian. Guru menggunakan media pembelajaran yang bersifat konkret untuk membantu proses pembelajaran berhitung pembagian. Media pembelajaran sederhana yang biasa guru gunakan dapat berupa lidi, buah-buahan, dan media lainnya yang terdapat dilingkungan sekitar peserta didik. Pada pembelajaran berhitung pembagian sederhana serta mengajarkan konsep sisa pada pembagian tersebut, guru menggunakan metode pembelajaran seperti metode ceramah, metode diskusi, dan metode demonstrasi serta diiringi dengan model pembelajaran yang menarik. Guru juga melakukan sedikit permainan yang dapat berupa peregangan atau yel-yel sebelum memulai pembelajaran, sehingga peserta didik akan lebih termotivasi dan tertarik dalam mengikuti proses pembelajaran. 
Hal tersebut adalah salah satu stretegi yang terdapat pada strategi pembelajaran berhitung pembagian yang digunakan. Guru juga membantu peserta didik dengan menggunakan media pembelajaran dalam mengenalkan konsep membagi, pembagian sederhana, dan konsep sisa seperti menggunakan media sederhana yang ada disekitar peserta didik. Sanjaya dalam Supinah (2007:126) mengatakan bahwa strategi pembelajaran merupakan suatu kegiatan pembelajaran yang harus dilakukan oleh guru dan peserta didik agar tujuan pembelajaran dapat dicapai secara efektif dan efisien. Strategi yang digunakan dapat berupa strategi pembelajaran langsung, strategi pembelajaran tidak langsung, dan strategi lainnya yang mendukung jalannya suatu proses pembelajaran. Kem dalam Husaini (2017) mengatakan bahwa staretgi pembelajaran adalah suatu kegiatan pembelajaran yang harus dikerjakan guru dan peserta didik agar mencapai tujuan pembelajaran dengan efektif dan efesien.

Pada saat pembelajaran berlangsung, guru memiliki dua strategi pembelajaran yang diterapkan ketika proses belajara berlangsung Strategi pembelajaran yang diterapkan oleh guru adalah seperti strategi pembelajaran langsung, dimana pembelajaran guru lebih dominan atau berpusat pada guru, yaitu seperti dengan menggunakan metode ceramah, praktik, latihan dan demonstrasi. Metode ceramah yang guru gunakan juga termasuk strategi yang diterapkan dalam proses pembelajaran berhitung. Peserta didik masih perlu dibimbing dengan menjelaskan terlebih dahulu mengenai berhitung pembagian. Kemudian guru mempraktikkan operasi hitung pembagian kepada peserta didik terlebih dahulu, setelah guru mempraktikkan lalu guru mendemonstrasikkan dengan menerapkan hasil yang telah dicontohkan tersebut. Yang kedua, dengan menggunakan pembelajaran tidak langsung, dimana peserta didik banyak terlibat didalam proses pembelajaran sehingga adanya interaksi antara guru dan peserta didik. Adapun hal-hal yang termasuk dalam pembelajaran tidak langsung, seperti guru memberikan kesempatan kepada peserta didik untuk mempraktikkkan pada operasi berhitung pembagian dengan menggunakan media sederhana yang disediakan oleh guru.

Peserta didik juga bekerja sama atau berkerja seacara berkelompok untuk menyelesaikan proses operasi hitung pembagian. Karena guru mengatakan bahwa dengan bekerja sama peserta didik yang masih belum bisa operasi hitung pembagian, dapat lebih mudah memahami jika dengan sesama teman lainnya. Biasanya Strategi ini biasanya dapat membantu peserta didik agar belajar dengan baik, dan guru hanya berperan sebagai fasilitator yang akan membantu peserta didik dalam proses pembelajaran. Maka dari itu dapat disimpulkan bahwa guru menerapkan strategi pembelajaran langsung dan strategi pembelajaran tidak langsung pada operasi berhitung pembagian untuk melancarkan dan membantu peserta didik dalam pembelajaran operasi berhitung pembagian. Sehingga pelaksanaan menggunakan strategi merupakan suatu hal yang dapat berinovasi dan kreasi guru dalam proses pembelajran supaya pembelajaran tiak terkesan membosankan dan menonton bagi peserta didik.

\section{PENUTUP}

Dari hasil penelitian dapat disimpulkan bahwa guru menggunakan strategi pembelajaran baik berupa strategi pembelajaran langsung yaitu strategi pembelajaran yang lebih berpusat pada guru, maupun strategi pembelajaran tidak langsung yaitu peserta didik banyak terlibat dalam bentuk tindakan dan guru hanya sebagai fasilitator yang akan membantu proses pembelajaran peserta didik. Dalam mengenalkan konsep membagi, guru menggunakan media pembelajaran sederhana yang dapat membantu dalam proses berhitung pembagian, adapun media sederhana yang biasa digunakan oleh guru dalam proses operasi hitung pembagian yaitu seperti lidi, buah-buahan, dan media sederhana lainnya yang ada disekitar lingkungan peserta didik. Pembagian sederhana yang dilakukan peserta didik juga diiringi belajar sambil bermain yang diterapkan oleh guru, seperti berhitung sambil menyanyikan yeyel yang sudah dibuat oleh 
guru. Adapun yang dilakukan guru dalam mengajarakan konsep sisa adalah dengan menggunakan metode ceramah, metode diskusi, serta demonstrasi. Adapun penelitian yang telah dilakukan peneliti yaitu mendapatkan temuan yang dapat dijadikan sebagai bahan masukan. Guru hendaknya lebih sering menerapkan strategi pembelajaran agar peserta didik dapat termotivasi ketika proses pembelajaran.

\section{DAFTAR PUSTAKA}

Fatimah. (2018). Strategi Belajar dan Pembelajaran dalam Meningkatkan Keterampilan Bahasa. Jurnal PBSI, 1 (2), 110.

Frengky. (2016). Model Pembelajaran Matematika Siswa Kelas Satu Sekolah Dasar. Jurnal Psikologi, 3 (2), 153.

Handayani, Sri. (2017). Upaya Meningkatkan Kognitif dalam Memperkenalkan Konsep Pengukuran Anak Usia Dini Melalui Metode Bermain Peran. Jurnal Unimus JKPM,4 (1), 22.

Herutman. (2017). Model Pembelajaran Matematika di Sekolah Dasar. Bandung: PT Remaja Rosdakarya.

Husaini, Rusdiana, dan Muzdhalifah. (2017). Penggunaan Strategi Role Play dan Strategi Modeling The Way Dalam Pembelajaran Aqidah Akhlak Terhadap Hasil Belajar Siswa kelas IV di MIN Bawah Barabai. AL-ADZKA Jurnal Ilmiah Pendidikan Guru Madrasah Ibtidaiyah, 7 (1), 170.

Khairunnisa. (2003). Strategi Pembelajaran Matematika Dengan Menggunakan metode Quantum Learning, Skripsi (Jakarta: Universitas Islam Negeri Syarif Hidayatullah).

Majid, Abdul (2013). Strategi Pembelajaran. Bandung: Remaja Rosdakarya Offset.

Majid, A. (2014). Strategi Pembelajaran. Jakarta: PT Remaja Rosdakarya.

Priatna, Nanang, dan Ricki Yuliardi. (2018). Pembelajaran Matematika. Bandung: PT Remaja Rosdakarya.

Putra, Wija Sindu. (2015). Analisis kesulitan belajar Matematika Siswa Kelas II Pada Implementasu Kurikulum 2013 Di SD Se-Kecamatan Buleleng. Jurnal PGSD Universitas pendidikan Ganesha, 3 (1), 4.

Rosmala A, dan Isro'atun. (2018). Model-Model Pembelajaran Matematika. Jakarta: Bumi Aksara.

Rosyadi, Widia. (2016). Analisis Kesulitan Belajar Operasi Hitung Pembagian Pada Siswa Kelas IV SDN Di Kecamatan Winong Kabupaten Pati, Skripsi (Semarang: Universitas Negeri Semarang).

Sari, Luftia Renny. (2018). Peningkatan Ketrampilan Berhitung Mata Pelajaran Matematika Materi pembagian Bilangan Tiga Angka Menggunakan Media Dakon Pada Siswa Kelas 3 di SDI Sabilil Falah sukodono, Skripsi (Surabaya: Universitas Islam Negeri Sunan Ampel Surabaya).

Sugiyono. (2013). Metode Penelitian Kualitatif dan R\&D. Bandung: Alfabeta.

Sundaya, Rostina. (2016). Media dan Alat Peraga dalam Pembelajaran Matematika. Bandung : Alfabeta.

Supinah. (2009). Strategi Pembelajaran Matematika SD. Yogyakarta: Departemen Pendidikan Nasional.

Soemarmo, Utari. (2017). Penilaian Pembelajaran Matematika. Bandung: PT Refika Aditama.

Wahyuni, Sri.(2013). Metode Penelitian Kasus. Madura. UTM PRESS. 